\title{
Land Tenure and Conservation in Chure
}

\author{
Bijay Kumar Singh ${ }^{1}$ \\ ${ }^{1}$ Independent researcher in natural resource management, monitoring and evaluation \\ Corresponding author: singhbk@ntc.net.np
}

\begin{abstract}
Covering about 13 per cent of the total land area of Nepal, Chure is an environmentally vulnerable, fragile and sensitive zone. Recognizing this, the Government of Nepal has declared it as "Chure Environmental Protection Area" and has formulated a high level board called "President ChureTerai-Madhesh Conservation Board" to oversee the conservation activities in the region. Based on a review of literature and a decade long engagement of the author in the conservation in Chure, in this paper, I explore the status and issues related to the management of and land tenure in the Chure region. I find that land tenure is one of the most contested and challenging issues of conservation in Chure. With the presence of significant human settlements near to Chure Environmental Protection Area, the boundary is contested, particularly after the unilateral designation by the government; issues also remain around the rights to utilize forest resources. In fact, these factors have resulted in over exploitation of the resources, mainly by the upstream communities. I conclude the paper arguing for a broader, holistic approach that integrates upstream and downstream ecosystems in such a way that strengthens the historical socio-ecological links between the Chure region and the Terai so as to bring positive impacts for both.
\end{abstract}

Key words: Chure, conservation, land tenure, Nepal, stakeholder

\section{INTRODUCTION}

Sustainable management of forest has been at the heart of forest policy debate in Chure ${ }^{1}$, especially in the last couple of years. The region is of high ecological and socio-economic significance and therefore has drawn the attention of diverse actors, including politicians, policy makers, local communities, downstream communities, professional groups and civil society organisations. Its unique fragile geological formation, major stock of commercially valuable Sal (Shorea robusta) forest, rich biodiversity, watershed services for downstream Terai, and heavy environmental degradation provide ample ecological rational for its conservation. The heavy dependence of about four million local people, who

1 Chure is also called 'Churia' or 'Siwaliks' in different literature and different parts of country and beyond. are living in Chure (including Bhawar ${ }^{2}$ ), managing local forest resources and mobilizing several local natural resources (e.g., forest, sand, stone, and water) to generate livelihoods and revenues, shows the socio-economic significance for the sustainable management of the region. Sustainable management of Chure is a national priority programme of the Nepalese government and the government has experimented with different policies and programmes in this region over the last five decades. As a part of its attempt, the government has recently declared it as 'Chure Environmental Protection Area' and has formed an integrated programme - Rastrapati Chure-TeraiMadhes Conservation Programme - to

2 Bhawar region is a buffer area which seperates the Terai from Chure. Although quite thin in its width, the Bhawar region sediments the sand and boulders as well as mud that comes during the monsoon season from the north. 
plan and implement conservation and management activities. Consequently, the policy intervention has drawn strong responses both in favour and against this attempt. While some of such concerns are genuinely linked to the long-term sustainability of Chure, many others are guided by contemporary politics and the specific interests of conservation actors. It appears that the interest based politics around Chure management policies and programmes may, in the long run, undermine the genuine concerns of ecological sustainability of Chure and the socio-economic well-being of the people living in and around it. Therefore, it has become an urgent task for researchers to understand the core factors that play pivotal roles in the sustainable management of Chure and inform a more enlightened debate on suitable policies and practices of natural resources management in Chure.

The paper is divided into six sections. Section two presents the background situation of the Chure region including its geography, boundary, population, land use and land tenure. Section three highlights the environmental changes observed in the region. While section four talks about the legislation, institutions and preliminary effects of the Chure conservation programme, section five discusses how it relates to issues of land tenure. Finally, section six concludes the paper with some points indicating the way forward to address the contemporary tenure related issues.

\section{BACKGROUND OF CHURE: GEOGRAPHY, BOUNDARY, POPULATION, LAND USE AND LAND TENURE Geography of Chure}

The Chure region spreads as a contiguous landscape across 36 districts (out of 75) from the East to the West of Nepal. It extends from 120 meter to nearly 2,000 meter elevation, having a series of low hogback ridges (10 - $50 \mathrm{~km}$ width) in a sinuous pattern. It is the first and lowest ridge of the Himalayan mountain system and occupies a strategic location between the Mahabharat range of Mid-hills in the North and the Terai plains in the South. It is geologically young and composed of unconsolidated loose materials originated from soft rocks (e.g., mudstone, sandstone, silt stone and shale). Soils are mostly shallow, coarse textured and formed on sedimentary rocks.

The Chure region constitutes $1,767,900$ hectare, which is about 13 per cent of the total area of Nepal. The region can be can be categorized into hills, narrow gorges, and Dun/valleys. Areas of these subregions are given in the Table 1 .

Table 1: Area and Population of Chure by Sub-regions

\begin{tabular}{lll}
\hline Region & Area in hectare & Area in \% \\
\hline Chure hills & $1,348,955$ & 76.31 \\
Narrow Gorges & 88,077 & 4.99 \\
Dun/valleys & 330,868 & 18.70 \\
Total & $1,767,900$ & 100.00 \\
\hline
\end{tabular}

Source: Interpretation and analysis of Google Map 2014 and Landsat Map 2014

The Chure region has different land features, information about which, such as river-bed, dissected land, and different levels of slopes, are given in Table 2. 
Table 2: Land Features in the Churia Region.

\begin{tabular}{llllllll}
\hline Landform & \multicolumn{2}{c}{ Dun valley } & \multicolumn{2}{l}{ Chure hill } & \multicolumn{2}{c}{ Total Chure region } \\
\hline & $\begin{array}{c}\text { Area in } \% \\
\text { hectare }\end{array}$ & $\begin{array}{l}\text { Area } \\
\text { hectare }\end{array}$ & in $\%$ & \multicolumn{2}{c}{$\begin{array}{l}\text { Area in } \\
\text { hectare }\end{array}$} \\
\hline River bed & & & 651 & 3.60 & 65,100 & 3.60 \\
Dissected land $\left(0-20^{\circ}\right)$ & 8,300 & 14.50 & 53,300 & 2.90 & 61,600 & 3.30 \\
Gentle slope $\left(<5^{\circ}\right)$ & 48,900 & 85.50 & 354,100 & 19.40 & 403,000 & 21.40 \\
Moderate slope land $\left(<20^{\circ}\right)$ & & & 88,800 & 4.90 & 88,800 & 4.70 \\
Steep slope land $\left(>20^{\circ}\right)$ & & & $1,260,500$ & 69.20 & $1,260,500$ & 67.10 \\
Total Chure region & 57,200 & 100 & $1,821,800$ & 100.00 & $1,879,000$ & 100.00 \\
\hline
\end{tabular}

Source: LRMP (1986)

\section{Boundary of Chure}

It is difficult to delineate the boundary of the Chure region, particularly along the Mahabharat range, in many parts of the country. However, geologist Dr. Pradeep Paudel, who visited the Chure area from Mechi to Mahakali during the Master
Plan Preparation of Chure in 2016, has identified the tentative border between Chure and Mahabharat in various NorthSouth highways based on the availability of different lithological materials and geographical features associated with these regions (Box 1).

\section{Box 1. Some Examples of Chure and Mahabharat boundary delineation}

- Jor Kalas is tentatively the boundary line between Chure and Mahabharat in Mechi highway, as mudstone and sandstone (indicator of Chure) and shale and slate (indicators of Mahabharat) meet there.

- Bhedetar is the tentative borderline between Chure and Mahabharat in Dharan-Dhankuta highway, as weathered sandstone (indicator of Chure) is observed to the south and gritty phyllite and quartzite (indicator of Mahabharat) are observed in the Bhedetar area.

- Kokajor Khola separates the Chure from Mahabharat range in the Barahkshetra area, where red purple mudstone (indicator of Chure) are observed on the left bank of stream, and slates (indicator of Mahabharat) are observed on the right bank.

- There is a sharp boundary between Chure and Mahabharat Gaighat- Diktel highway, as the red purple and grey colored mudstone (indicator of Chure) ends suddenly at about 10 $\mathrm{km}$ far from Gaighat and, at the same point, highly fractured grey dolomite (indicator of Mahabharat) is observed.

- Patna Bhanjyang is the tentative borderline between Chure and Mahabharat in KatariOkhaldhunga highway, as thick bedded sandstone of Chure ends to the south of saddle point, while thinly foliated slate of Mahabharat can be observed to the north of saddle.

- Pipal Bhanjyang is the tentative borderline between Chure and Mahabharat in B.P. Highway, as grey sandstone of Chure is separated from the dolomitic limestone and slate of Mahabharat near Pipal Bhanjyang.

- Gimdi, Thula Durlung, and Mahankal village areas are the borderline between Chure and Mahabharat in Bagmati river, as mudstone of Chure and the black slate of Mahabharat meet there.

- Kisede Khola in Makwanpur clearly delineates the boundary between Chure and Mahabharat, as red purple mudstone of Chure is observed on the right bank and slates and quartzite of Mahabharat is presented in the left bank. 
- Churlung Khola, a tributary of Manahari Khola of Makwanpur district becomes a boundary of Chure and Mahabharat, as the left bank of stream is composed of red purple mudstone and shale of Chure and thinly foliated dark grey slates of Mahabharat are found on right bank. There are some black crushed zones as indicator of tectonic boundary as well.

- Jugedi and Kerabari are the tentative borders between Chure and Mahabharat along the Narayanghat-Muglin highway and Siddhartha highway, respectively, where red purple mudstone and grey sandstone beds of Chure meet with dolomitic limestone and black calcareous slate of Mahabharat.

- The North of Badachaur Bazar along the Gorusinghe-Sandhikharka highway is the tentative border of Chure and Mahabharat, as sandstone beds of Chure and hard shale and sandstone of Mahabharat meet there.

- Ranagaun is the tentative borderline between Chure and Mahabharat in the TulsipurSalyan highway, as we can observe both sandstone and black crushed zone of Chure and fissile shale of Mahabharat.

- Chingar Khola, a tributary of Bheri River, is the tentative borderline between Chure and Mahabharat, as thick-bedded sandstones of Chure finally terminate with beginning of highly fractured dolomite cliffs of Mahabharat.

- Godam Village on the right bank of Rangoon Khola, flowing from Budar to Jogbudha forms the boundary between Chure and Mahabharat, as red purple mudstone of Chure changes to slates and quartzite of Mahabharat.

\section{Population of Chure}

Based on the national census database aggregated at administrative ward level, there are 2,509 village development committees within 12 municipalities located in the Chure region. The total population of Chure is estimated to be 3.6 million covering 14 per cent of the total population of Nepal (CBS 2011). There is generally a low population density in the Chure region (Springate-Baginski et al. 2010); the average density is around 173 individuals $/ \mathrm{km}^{2}$. The proportion of female and male are 53 per cent and 47 per cent respectively and the average household size is 4.6 individuals. Based on development region, the Central region of Chure composes of the highest percentage of population (34\%) followed by the Mid-Western (23\%), Eastern $(23 \%)$, Western (16\%) and Far-Western (8\%) regions (Table 3).

Table 3: Population and Households in Chure Region

\begin{tabular}{|c|c|c|c|c|c|c|}
\hline \multirow{2}{*}{$\begin{array}{l}\text { Development } \\
\text { regions }\end{array}$} & \multirow{2}{*}{$\begin{array}{l}\text { Number of } \\
\text { households }\end{array}$} & \multicolumn{4}{|c|}{ Populations } & \multirow{2}{*}{$\begin{array}{l}\text { Population } \\
\text { density } \\
\left(\text { number } / \mathrm{km}^{2}\right)\end{array}$} \\
\hline & & Male & Female & Total & $\%$ & \\
\hline Far-Western & 52,310 & 134,234 & 147,210 & 281,444 & 8 & 96.70 \\
\hline Mid-Western & 177,003 & 395,280 & 442,069 & 837,349 & 23 & 142.85 \\
\hline Western & 134,529 & 279,211 & 319,433 & 598,644 & 16 & 203.47 \\
\hline Central & 265,485 & 583,777 & 634,750 & $1,218,527$ & 34 & 213.93 \\
\hline \multirow[t]{2}{*}{ Eastern } & 154,425 & 327,492 & 370,245 & 697,737 & 19 & 196.97 \\
\hline & 783,752 & $1,719,994$ & $1,913,707$ & $3,633,701$ & 100 & 173.42 \\
\hline
\end{tabular}

Source: CBS (2011) 


\section{Land Use in Chure}

The Chure region approximately constitutes of 26 per cent of the natural forest of the country. Of the total land in the Chure region, forests (including bushes and grasslands) constitute Table 4: Land uses in Chure region
$1,311,890$ ha $(74.18 \%)$, riverbeds cover 77,701 (4.39\%), and agricultural and other lands comprise 378,946 ha $(21.43 \%)$. Please see the Table 4 for the disaggregated data by Chure hills and Dun/valley.

\begin{tabular}{llllllllll}
\hline $\begin{array}{l}\text { Eco-region } \\
\text { of Chure }\end{array}$ & \multicolumn{2}{l}{$\begin{array}{l}\text { Agriculture and } \\
\text { others }\end{array}$} & \multicolumn{3}{l}{$\begin{array}{l}\text { Forest, bushes and } \\
\text { grassland }\end{array}$} & River beds & \multicolumn{2}{l}{ Total } \\
\cline { 2 - 10 } & Hectare & $\%$ & Hectare & $\%$ & Hectare & $\%$ & Hectare & $\%$ \\
\hline Chure hills & 189,593 & 13.16 & $1,202,461$ & 83.47 & 48,465 & 3.36 & $1,440,519$ & 100.00 \\
Valley/Dun & 189,353 & 57.73 & 109,429 & 33.36 & 29,236 & 8.91 & 328,018 & 100.00 \\
Total & 378,946 & 21.43 & $1,311,890$ & 74.18 & 77,701 & 4.39 & $1,768,537$ & 100.00 \\
\hline
\end{tabular}

Source: Interpretation and analysis of Google Image 2014, and Landsat 2014

Of the forests, 3 per cent is conifers (Pinus roxburghii), 83 per cent hardwoods (with almost equal amount of Sal forest and tropical mixed forest), and 14 per cent mixed Chir pine and hardwoods. The majority of the forests (76\%) in this region lie outside the protected areas, whereas the remaining forest lies in the protected areas (core zones - 18\% and buffer zones - 6\%) (DFRS 2014). Most of the Chure forests are accessible and lie close to the densely populated area (e.g., Terai), and thereby are under high pressure.

\section{Land Tenure in Chure Region}

From the land tenure perspective, out of the total forest area in Chure, it is estimated that the largest portion is under the government-managed forest, directly administered by the Department of Forests. In such forests, the central government has the formal rights over the forest resources and forestlands. However, local communities are generally allowed to use non-timber forest products for subsistence use. The second largest area of forest in Chure in terms of land tenure is managed as community forests, which have been handed over to the local communities for their management and utilization. There are 2,837 community forests in Chure, through which 490,547 households are directly engaged in forest management (DOF 2013). There are also a few parcels of forests leased to poor households as Leasehold Forests (e.g., in Makwanpur, Chitwan, Sindhuli, Udaypur, Dadeldhura and some other districts). However, there is no data available on the number and area of leasehold forests in the Chure region. The communities managing the forest have rights to use the forestland and resources without changing the major land use type. There is also one Collaborative Forest in Dhanusha district, which has 2,190 hectares of forest, and one Protection Forest in Surkhet district, which has 6,361 hectares and is administered by the local entity under the Department of Forests. The protected areas that lie partially in the Chure region include the Parsa Wildlife Reserve, and the Chitwan, Banke and Bardia National Parks and their respective buffer zones. These protected areas are administered by the Department of National Parks and Wildlife Conservation. 
Private lands of Chure region can be categorized into those located in the valleys and the hills. Private lands located in the valleys (e.g., Udaypur, Sindhuli, Makwanpur, Chitwan, Dang and Surkhet) have official land title (i.e., Lalpurja) but most of the agricultural lands located in the hills lack official land title. However, local people, who have migrated or settled in the Chure hills after the land survey, are also using the lands without official land title.

A study of Narayankhola of Sarlahi, which is located in the Churia region, reveals that only 3 per cent $(15 \mathrm{ha})$ of the total cultivated land (486 ha) has been registered, owned by 9 families only, whereas there are 675 families in the VDC (93 per cent of $\mathrm{HH}$ was covered by the census). The same study reveals that in Sarlahi 83 per cent of the cultivated land is unregistered whereas in Mahottari 65 per cent of the cultivated land is unregistered, that is 74 per cent of the total cultivated land is unregistered (CSRC 2005).

Most of the public institutions (e.g., schools, health posts, and local government offices), play grounds, religious places (e.g., temples and Gumbas) and market place in the Chure hills are in forest lands. Though such public institutions and local communities do not have official land title, they have access, uses and certain level of control over such lands.

\section{ENVIRONMENTAL CHANGES IN THE CHURE REGION}

Until 1950, the Chure forests were dense, and the then Rana rulers and their followers controlled most forests under birta $^{3}$ tenure (Mahat et al. 1986; Regmi

3 The Birta system owes its origins to the divestiture of ownership in the land by the state in favor of individuals; it was a form of privileged land ownership that enabled Birta owners to exploit the land resources for their benefits. It served the social, economic, and political needs of the ruling classes of Nepal before 1951, and was synonymous with inequality.
1999). After the abolishment of the Rana regime in 1951, the Nepalese government promulgated the Forest Act 1957, which nationalized all the forests, bringing them back under government control. However, it has been held responsible for widespread forest destruction, as it alienated and dispossessed local people from their forest resources and disrupted traditional forest management systems (Barton 2001; Blaikie and Springate-Baginski 2007). Further degradation of Chure forests was due to the Land Tax Act 1977, which defined forested land as government land, spurring local inhabitants to chop down the trees on their farms, so their farms/lands would not be claimed by the government (Gilmour and Fisher 1991; Hobley and Malla 1996).

During the late 1960s and early 1970s, Nepal was portrayed as a country facing massive environmental degradation in its hilly regions, including the Chure. It was claimed that this deforestation was responsible for flooding in the Terai and in the Gangetic plains in India and Bangladesh (Ives and Messerli 1989). In response, the Government of Nepal formulated the National Forestry Plan 1976 and later promulgated the Panchayat Forest and Panchayat Protected Forest Rules in 1978 to encourage local people to participate in forest conservation and management (Gilmour and Fisher 1991; Hobley and Malla 1996). Unlike in the Mid-hills, only a fraction of the total area of Chure forest was handed over to the local communities under this regime; the rest was managed as government-protected forest (Gilmour and Fisher 1991; Hobley and Malla 1996).

The eradication of malaria, the construction of the East-West highway that passes from the foothills of Chure throughout the country, the construction of the NorthSouth highway along the Chure region, and the other local roads have made it easy to migrate to and to access lands in Chure. 
Such factors have been pull factors in increasing the settlements and population (including towns and urban centres) in the Chure region. Consequently, the population and the value of land in Chure have rapidly increased, and thereby land tenure in the region has been affected.

There was about $631.55 \mathrm{~km}^{2}(\sim 81 \%)$ forest cover in the Eastern Chure (MechiKoshi) in 1958, but it declined to 477.23 $\mathrm{km}^{2}(61.2 \%)$ in 1992 (Bhuju et al. 2007). It appears that 38,051 ha of forest in Chure has been lost from 1995 to 2010 with -0.18 per cent annual rate of forest cover change (DFRS 2014). However, such decline is not consistent throughout the Chure region; while the forest area has decreased in 27 districts, it has slightly increased in 9 districts (in Arghakhanchi, Banke, Morang, Ilam, Sunasri, Chitwan, Kapilvastu, Dhankuta and Pyuthan) (DFRS 2014). The main reason for deforestation and land use change is seen to be the expansion of agricultural land. Besides changes in land use pattern, about 1 per cent of the productive forestland was also converted into degraded shrub land in the same period.

\section{CHURE CONSERVATION PROGRAMME: LEGISLATION, INSTITUTIONS AND PRELIMINARY EFFECTS}

\section{Legislation}

Around three years ago (2071/03/02 B.S.), the Nepalese government designated the Chure region as the "Chure Environmental Conservation Area' as per Article 10, SubArticle (1) of the Environment Protection Act 1997. The provisions of Section 10 of the Environmental Protection Act 1997 are: (1) Government of Nepal may, by a notification in the Nepal Gazette, maintain any place within Nepal containing natural heritage or aesthetic, rare wildlife, biological diversity, plant, and places of historical and cultural importance, which are considered extremely important from viewpoint of environment protection, as an Environment Protection Area, and (2) the activities of any Act, as prescribed, may be prohibited in the Environment Protection Area pursuant to Sub-section (1). To implement these provisions, the government also formulated the Environment Protection Rules 1997 in which several actions are prohibited inside Environmental Protection Areas (Box 2). Despite such actions, nothing contained there shall be deemed to prevent the execution of any function permitted by the Ministry of Forest and Soil Conservation (MoFSC) for the management and development of the environment conservation zone.

Box 2: Prohibited Actions Inside the Environmental Protection Areas

1. To damage, destroy, demolish, remove, block or cause harm or loss in any other manner to the natural heritages or scenery beauty;

2. To buy or sell, trade-in, hunt, or cause any harm to the wildlife;

3. To take any action in such manner, which may cause adverse effect into the biodiversity;

4. To cut, fall, remove, block, uproot or cause any loss or harm to any plant;

5. To damage, replace, destroy, remove or demolish any site of historic and cultural signification, or affix any poster or similar other document or picture in such site, or take otherwise any action, which any case harm to such site;

6. To use electric current or botanical or any other types of harmful chemicals into any river stream, rivulet, fountain, pond, lake or any other sources of water; 
7. To transform the genetic make-up through any types of domestic animals;

8. To excavate mines or remove minerals, boulders, soil, concrete or other materials;

9. To operate hotels, lodges, public transport, health posts, schools, huts or similar other services;

10. To enter into the environment protection zone without permission of the authority empowered by the MoFSC;

11. To cause any loss or damage to any wire-fences, marks or signs or any other objects installed inside the environment conservation Zone.

In addition, the government has taken other regulatory decisions to manage the Chure region. For instance, in the context of heavy exploitation of stones, sand and gravels from the Chure region, the Ministry of Commerce and Supply, through a notice dated 2071/3/23, banned the excavation and export of such resources from the Chure region (effective from 2071/4/1), resulting in a positive impact towards the conservation in Chure. Similarly, Ministry of Science, Technology and Environment, through a notice dated 2071/3/17, clarified the Environment Protection Rule 30 (2) that some works are not prohibited although they are mentioned in the section 10 (1) of the Act. Such works include: to work according to approved operational plans, approved programs and user groups under the National Park and Wildlife Conservation Act 2029, Soil and Watershed Conservation Act 2039 and Forest Act 2049; to make quarry of mines or minerals, stone, soil, gravel or other materials according to approved protocol, and procedures for internal consumptions as per Rule 30(1) of Environment Protection Rules 2054; and to operate hotel, lodge, public transport, health post, schools, public place or other services or get entry into the Environmental Protection Area as per approval taken according to Rule 30(1) "Jha" of Environment Protection Rules 2054. The MoFSC has recently formed a committee to formulate a separate Chure Conservation Act to better adapt the regulatory provisions made under environmental and forestry legislations in the unique socio-ecological and geopolitical contexts of the Chure region. However, the progress in this regard, so far, has not been publicly available.

\section{Institutions}

Recognizing the socio-ecological significance of the Chure region, the government has recently been trying to conserve and manage this region by taking several institutional initiatives, including development interventions. The MoFSC prepared the 'Chure Area Programme Strategy' in 2008 and initiated a special programme called the 'Rastrapati Churia Conservation Programme' in 2011. The latter programme covered 27 districts of the Chure region and emphasized the following programmes: integrated management of land, water and forests for ecological balance; strengthening, and involvement of local people from the Chure and Terai for the management of upstream-downstream linkages; and site specific and off-site management of environmental systems (MoFSC 2011).

Recently, the government has gazetted Chure as a special Protection Region covering 36 districts (MoFSC 2014). Also by exercising the power conferred by Section 3 of the Development Board Act 1956, the government formed a high level 'President Chure-Terai-Madhesh Conservation Development Board'4 (hereafter 'Board') to formulate and

4 This Board includes a full time Chairperson equivalent to State Minister, four board members equivalent to Assistant Minister, and a member secretary with five-year tenure. 
implement Chure protection policy and programmes. However, the policy and programme need to be approved by the MoFSC before implementation. If the rules and programmes have financial implications, the MoFSC approve in consultation with the Ministry of Finance. The Board may enact and implement necessary guidelines and procedures in order to implement the rules, programmes and periodic orders. In addition, the Board has to perform several activities (Box 3).

\section{Box 3: Function, Duty, Power and Responsibility of the Board}

- Preparation of Chure Conservation Strategy and Master Plan: Chure conservation strategy and master plan (for 20 years) cover the programmes like reduction of the problems caused by excessive and random exploitation of natural resources and unscientific land use, conservation of whole ecosystem and biodiversity, conservation and use of water resources, identification and use of traditional ecological knowledge and skills of Chure area conservation, engage local communities in the management of Chure, and improvement of local communities' livelihood.

- Preparation of Integrated River System Management Programme: Integrated river system management programme includes: (i) treatment of cleavage and gorge of the Chure area and management of river system up to 'No Man's Land' (i.e., Das Gaja), (ii) tree plantation in high lands, and (iii) productive agricultural cultivation. The Board prioritises the rivers for implementation of programmes based on several factors, including the upstream-downstream linkage.

- Identification and Treatment of Vulnerable Areas: The Board keeps the data of vulnerable areas, including landslides in the hills and treat the areas that may cause threat to human settlement by developing appropriate technologies. The Board, with the technical support of Department of Environment, Tribhuvan University, has identified vulnerable areas in Chure for treatments.

- Improvement in Agricultural System and Income of Chure Communities: The Board seeks comprehensive and positive roles of local communities in minimizing the socioecological risks in Chure by engaging them in several poverty reduction and livelihood support activities. Some of such activities include agricultural system improvement, soil and water conservation, pastureland management, fruit trees plantation, animal husbandry modernization, private forests promotion, herb cultivation, community empowerment, infrastructure development, eco- tourism development, business skill enhancement, and emission management. The Board fosters collaboration and partnership with a range of government and non-government organizations, and donor communities.

- Research and Technology Development: Through the collaboration and partnerships with different experts and organizations (e.g., universities and non-government organizations), the Board carries out research, knowledge management, technology development and communication regarding different aspects of Chure management such as geographies, ecosystems, agriculture, biodiversity, and water.

- Accumulate technical and financial resources: The Board is responsible for the accumulation of technical and financial resources required for the protection of Chure area through partnership, collaboration, or any other means.

- Monitoring and evaluation: The Board is responsible not only for the implementation of the conservation activities but also for monitoring and evaluation of those activities. 
In 2016, the Board prepared 'Protocols for Development Constructions for Environment Conservation in Chure Area', which provide not only the primary basis on which to access natural resources and services but also to guide development works in the Chure region. These protocols were prepared in close consultation with concerned stakeholders. These protocols cover forest management and plantations; national/local/agricultural road and bridge construction, improvement or maintenance; irrigation canal construction and maintenance; public or community building construction; drinking water system development (e.g., reservoirs construction and pipe distribution), dangerous chemicals management, and collection of river materials (e.g., stones, gravel, sand and soil) and mining.

The Protocols distinguish the Chure region as either 'highly sensitive', 'sensitive' or 'normal' zones. Highly sensitive zone consists of naked areas, landslide and multiple gully areas, and $>31$ degree slope areas, which have to be completely protected (except collection of fallen trees) and trees, poles, regenerations and seedlings have to be maintained. Sensitive zone lies between 21-31 degree slopes, where trees having more than $60 \mathrm{~cm}$ diameter could be removed but equal distribution of trees in each 0.5 hectare area and sufficient density of vegetation should be maintained. In the normal zone, which lies below 21 degree slope, shelterwood forest management system can be carried out according to the rotation age of main or dominant species (PCTMCDB 2015).

As the Chure region has complex sociocultural, ecological, economic and geopolitical processes, its conservation and management is associated with multidimensional and multi-sectorial issues. The MoFSC or the Board alone cannot conserve and manage Chure and therefore, several institutions are given opportunities and currently engaged with a range of interventions in the Chure region. A brief inventory of such institutions and their roles and programmes is briefly highlighted in Table 5 . The project 'Sustainable Land Management in the Chure Region' that aims to empower local communities to sustainably manage the forest and promote community-based conservation is also being implemented in Makwanpur, Parsa, Bara and Rautahat districts of the Chure region (WWF 2013). With the financial support of the Global Environment Fund, and in collaboration with the MoFSC, Ministry of Land-reform and Management, Ministry of Agricultural Development, and Ministry of Science, Technology and Environment, the World Wildlife Fund Nepal implemented the project. 
Table 5: Institutions Directly/Indirectly Related to Resource Management and Use in the Chure Region

Institution
Government of Nepal
Rastrapati Chure-Terai Madhesh
Development Board 2014

Direct/Indirect Actions/Relations in Chure Region

Declare "Chure Environmental Protection Area" in 2014 under the Environment Protection Act 1997

Development Board 2014

Department of Forest and its offices

Prepare and implement long-term, medium-term and annual policy, strategy, programmes and implement them through government line agencies and nongovernment organizations. The Government has approved the Master Plan for Chure Conservation Area. The Board is fighting against illegal encroachers and illegal extraction of natural resources from the Chure region.

Protect the forest (and its area) in the Chure region. In some of the locations, the district forest offices have regained the encroached forest area and established forest plantations.

Department of National Parks and Wildlife Conservation and its offices

Protect forest (and its area) from illegal encroachers in protected areas of the Chure region.

Land related 'Commissions' of the government

Community Forest User Groups

Collect information about public lands and their users, landless and poor households, and issue permission letter for land tenure rights.

Prepare, implement and monitor the community forestry programs and activities including the land tenure rights. In Chure, many CF areas have been encroached in an organized way to fulfil both public and personal interests and many communities are struggling against such encroachments.

Federation of Community Forest Users Nepal (FECOFUN)

Leasehold Forest User Groups

Protection Forest Committee

Advocate for the rights of forest users against the declaration of Chure as conservation area and formation of the Board.

Prepare, implement and monitor the Leasehold Forestry programme and activities including the land tenure rights for 40 years and extension for another period.

Prepare, implement and monitor the conservation oriented forest programs and activities including the land tenure of its territory.

Collaborative Forest Management Prepare, implement and monitor the collaborative Committee forest management programs and activities, including protection of forest products from encroachers and illegal harvesters and advocate for land tenure rights. 
Community Self-Reliance Center

Animal Herders (individual households)

Local governments, including rural and urban municipalities

International/national/community level non-government organizations

Forest encroachers in Chure region (Household, organizations such as schools, market centers, health posts, play grounds, community based organizations, and local governments)
Advocate for land tenure rights for landless households, and those, who have already occupied public or forestlands in the Chure region.

Free riders for grazing; keeping Goth (animal sheds) without permission and found widespread in the Western Chure hills.

Representative of rural and urban municipalities sign as eyewitness in the informal (Gharayasi) land related documents. Local governments provide several services such as drinking water, road, electricity and educational facilities in illegally encroached areas of the Chure region.

Extend water, road, electricity and educational facilities in illegally encroached areas in the Chure region.

Encroach and use forestlands illegally for their own private or institutional use without taking official land title certificate or permission from the concerned government authority.

\section{Preliminary Effects}

The Government's decision regarding the ban on export of gravel, sand and stones $(2071 / 4 / 1)$ has forced the closure of hundreds of plants that used to process stones, gravel and sand into finished goods. It has drastically reduced commercial excavation, mining, and collection of these goods from the Chure and its river systems and thereby has massively reduced the pressure on Chure ecosystems. It has also reduced dust pollution in the vicinity of plants and nearby villages, and pressure on road traffic, and may even have increased the life of roads in the region, including the Terai. However, it has led to reduced local employment and revenue of the few district development committees and village development committees in the Terai.

Though there was no restriction in collecting non-timber forest products, a decision was made to ban the harvesting of forest products, particularly of timber from the Chure region. This has reduced the 'unmanaged' harvesting of timber from community forests for commercial purposes, and has a direct positive impact on Chure conservation, as it has helped to increase greenery and vegetation. However, FECOFUN in Nepal has raised concerns at local to national levels that such a decision curtails the rights of local communities over the forest resources. Gradually, Chure issues have not only been the subject of discussions at national forums but have also been published and broadcasted by most of the national and local media (e.g., radio, television and newspaper). For the first time, the Chure region has been discussed at community, district, regional and national level forums, resulting in the creation of greater awareness of the issues in the region. Ultimately, the issues related to 
Chure conservation and management have been one of the agendas of debate in the Environmental Committee of the Parliament and the Parliament as well.

The Chure conservation programme has launched several construction programmes, including check dams, water conservation ponds and other soil conservation structures in the prioritized upstream rivers and embankments in the downstream rivers to save land from erosion. For instance, the width of Ratu river of Mahottari, and Jaladh river of Dhanusha have been drastically reduced and hundreds of hectares of lands have been recovered by conservation plantation and construction of check dams and conservation ponds in many creeks in the upstream, and by the construction of embankments and a ban on the collection of river products. The programme has also installed a numbers of biogas plants, which has reduced the pressure on forests for fuelwood. However, there is an acute shortage of such initiatives, as shown by the gap between demand and supply.

\section{KEY ISSUES AND CHALLENGES}

Due to its loose structural nature of round stones, gravel, coarse sands, mudstone and sandstones, the Chure region is fragile and environmentally sensitive. Compounded by less environmentally-friendly human activities, land and other resources in the Chure region are being eroded rapidly. One of key human-induced issues in the Chure region is the cultivation of agriculture crops in steep slopes following 'shifting cultivation'. Many cases show that migrated people have encroached the forest, practiced agriculture for a couple of years, and then sold their land to other people and moved to another location. This process may be repeated several times. Similarly, open grazing and keeping of massive animal sheds of goat and domestic animals have been practiced, particularly in the Far-Western region as free riders. Though very few households have are benefitted through such practices, communities and settlements in the downstream are negatively affected due to the degradation of the Chure hills. In addition, over-exploitation of resources (e.g., land, stone, water, sand and soil) by the government, community and private agencies has direct negative impacts on inhabitants, infrastructures, lands and properties in both Chure and the Terai. Innumerable large and small landslides occur year after year in this region, particularly in the steep area and thereby both cultivable lands and human settlements are threatened. Rivers originating and flowing from Chure deliver large amount of stones, pebbles, sand and soil to the lowlands and fill the bottom of rivers every year, causing floods, riverbank cutting and calamities (e.g., threat to or loss of cultivable land and human settlements) in the Terai area. Many households in Chure and the Terai who owned land are either becoming landless or owners of marginal land, particularly due to increasing landslides, widening river and growing siltation effects (Singh 2010).

Land tenure is a critical issue in Chure region as the majority of the settlers, either old or newly migrated, do not have official land titles in their names. They have, however, been using their land for years. Even today, after the completion of the official land survey, people are migrating into this region, encroaching the forest areas and practicing agriculture or establishing new settlements without 
land title. Such encroachments have particularly been focussed in the core interior areas, road heads, and areas close to market centres. On many occasions, Chure forests have been encroached in an organized manner, motivated by political parties for their vote banks. In addition, despite a lack of legal recognition, the customary practices of land transactions (sale and buy) based on locally written papers (Gharayasi kagaj), institutionalized such transactions within the local communities, which has contributed to the complexity of land tenure in the area. In such situations, the landowners neither leave the land nor invest in the sustainable conservation and management of land and thereby negatively affecting the land and the local environment (MOPE 2016).

The construction of the alternative highway from Hetauda to Dharan that passes through the Chure region, projected to be completed within three years since it is a 'Priority 1 Project' of the government, will drastically increase urbanisation. This is bound to add pressure on the resources in the Chure region. Ultimately, it will also massively affect the land tenure of inhabitants in the region.

There are also many public institutions such as health posts and schools that have constructed their office buildings on encroached land without legal entitlements. It has been reported in a number of locations that an entire village has been settled by encroaching the national forests or community forests, where many government agencies and non-government organizations are supporting in providing goods and services such as road construction, electricity, drinking water, school construction and health post establishment. Such services not only gradually legitimize the local communities' living in that locality but also encourage others to migrate to the same village or other areas, anticipating to be established in the future. More recently, landless communities of the Chure region, particularly in Mahottari and Sarlahi districts, have been putting organized efforts to acquire formal land titles with the support from non-government organization (e.g., Community Self Reliance Centre).

The district forest offices, which are responsible for stopping forest encroachment, are not effectively monitoring or controlling such encroachments. They can neither remove local communities from their land nor can they certify them for land title. The government made several periodic efforts (e.g., formation of 'commissions') to provide land and land title to the landless so as to solve the problem permanently. However, the problem remains the same; it appears that the issuance of a permission letter for land tenure rights or land title in Chure is an on-going issue. It is partly due to the politically motivated interests of such commissions.

Despite several stakeholders including government, politicians, journalists, conservationists, and upstream and downstream populations, agreeing that there is a need for special efforts to conserve and manage the Chure region, strong money and muscle power of contractors have been influential regarding such efforts and the utilization of its resources. Also stakeholders have different, at times opposing, opinions and perspectives regarding management strategies. Such views make collaboration and partnership among stakeholders complicated and challenging. 
There is lack of national policy and strategy on how to tackle land and forest tenure issues in the Chure region. The Forest Act 1993 and Forest Regulations 1995, which are effectively implemented in the mid-hills region, are not effectively implemented in the Chure region. Though the Land Use Policy 2012 has been formulated for the management of the countries' land as a whole, there is a lack of a legal framework (i.e., act and regulations) for its implementation. Despite the continued encroachment of the Chure forest, there is a lack of national level policy to solve the problem associated with land tenure in the Chure. Although the MoFSC has prepared a Guideline on Forest Land Use for Other Purposes, it has not been effectively enforced.

\section{WAY FORWARD}

A comprehensive study about the land tenure situation would perhaps be a good start to address socio-ecological issues in the Chure region. Existing site-specific case studies and fragmented studies about land ownership and forest tenure could constitute the foundation for such study. Based on such studies, the government may organize consultations with concerned stakeholders, including local communities, to gather their views regarding the preparation and enforcement of required policy and legislative frameworks.

The federal government may coordinate with state and local governments to identify the potential solutions to sort out land tenure issues permanently. Such a solution needs to address current controversy in this region and surrounding these issues.

A Chure management plan may need to be viewed from the broader landscape perspective that integrates upstream and downstream ecosystems. Such a plan should strengthen the historical socioecological links between the Chure region and the Terai, and should be inclusive of both programmes and day-to-day practices in the area; this is necessary to bring positive impacts in both the Chure region and the Terai.

\section{ACKNOWLEDGEMENTS}

The author would like to highly appreciate geologist Dr. Pradeep Paudel, who gave the information of tentative borderline between Chure and (midhills) Mahabharat range in various North-South roads of Nepal from East to West. He would also like to earnestly thank Dr. Naya Sharma Paudel and Mr. Rahul Karki for their valuable comments for refining the paper.

\section{REFERENCES}

Barton, G. 2001. Empire Forestry and the Origins of Environmentalism. Journal of Historical Geography, 27(4): 529-52.

Bhuju, U.R., Shakya, P.R., Basnet T. and Shrestha, S. 2007. Nepal Biodiversity Resource Book, Protected Areas, Ramsar Sites and World Heritage Sites (First Edition). ICIMOD, Government of Nepal, United Nations Environment Programme, Kathmandu, Nepal.

Blaikie, P. and Springate-Baginski, O. 2007. Understanding the Policy Process. In: O. Springate-Baginski and P.M. Blaike (Eds.), Frosts, People and Power: The Political Ecology of Reform in South Asia. London and VA: Earthscan and Sterling.

CBS. 2011. Nepal Population Report. Central Bureau of Statistics, Government of Nepal, Kathmandu, Nepal.

CSRC. 2005. Churia Conservation, Livelihoods and Land Rights: Unravelling the Complexities - A Report of Participatory Action Research in Mabottari and Sarlabi. Community Self Reliance Center, Kathmandu, Nepal.

DFRS. 2014. Churia Forest of Nepal. Department of Forest Research and Survey, Government of Nepal, Kathmandu, Nepal. 
DOF. 2013. Hamro Ban (2013). Department of Forest, Government of Nepal, Kathmandu, Nepal.

Gilmour, D.A. and Fisher, R.J. 1991. Villagers, Forests and Foresters: The Philosophy, Process and Practice of Community Forestry in Nepal. Kathmandu: Sahayogi Press.

Hobley, M. and Malla, Y.B. 1996. From Forests to Forestry: The Three Ages of Forestry in Nepal: Privatization, Nationalization and Populism. In: M. Hobley (Ed.), Participatory Forestry: The Process of Change in India and Nepal. Overseas Development Institute, Rural Development Forestry, London, UK.

Ives, J. and Messerli, B. 1989. The Himalayan Dilema. London and New York; Routledge.

LRMP. 1986. Kenting Earth sciences (1986). Land Resource Mapping Project, Government of Nepal, Kathmandu, Nepal.

Mahat, T.B.S., Griffin, D.M. and Shepard, K.R. 1986. Human Impact on Some Forests of the Middle Hills of Nepal: Forestry in the Context of the Traditional Resources of the State. Mountain Research and Development, 6(3): 223232.

MoFSC. 2011. Rastrapati Chure Conservation Programme. Ministry of Forests and Soil Conservation, Government of Nepal, Kathmandu, Nepal.
MoFSC. 2014. Cabinet Decision on Declaration of Chure. Ministry of Forests and Soil Conservation, Government of Nepal, Kathmandu, Nepal.

MOPE. 2016. Nepal National Action Programme (NAP) on Land Degradation and Desertification under the United Nations Convention to Combat Desertification (UNCCD). Ministry of Population and Environment, Government of Nepal, Kathmandu, Nepal.

PCTMCDB. 2015. Environmental Conservation Protocols for Development Works in Churia Region. Rastrapati Chure Terai-Madhesh Conservation Management Board, Kathmandu, Nepal.

Regmi, M.C. 1999. Thatched Huts and Stucco Palaces: Peasants and Landlords in $19^{\text {th }}$ Century Nepal. Delhi: Adroit Publishers.

Singh, B.K. 2010. Assessment of the Upstream Churia Hills and Downstream Terai Plains Linkage: An Environmental Services Perspective. Banko Janakari, 20(1): 17-23.

Springate-Bangiski, O., Bhatta, B. and Booker, F. 2010. REDD, Forest Governance and Rural Livelihoods: The Emerging Agenda. CIFOR, Bogor, Indonesia.

WWF. 2013. Sustainable Land Management in Churia Range. World Wide Fund for Nature, Kathmandu, Nepal. 